\title{
Potential of Sodom Apple (Solanum incanum L.) Fruit Extracts in the Management of Chilli Root Knot Disease in Nakuru County, Kenya
}

\author{
Charei Munene Waweru, Japhet Mburugu Muthamia, and Daniel Otieno Otaye \\ Department of Biological Sciences, Egerton University, Njoro, Kenya \\ Correspondence should be addressed to Japhet Mburugu Muthamia; jmuthamia09@gmail.com
}

Received 25 December 2016; Revised 10 April 2017; Accepted 26 April 2017; Published 16 May 2017

Academic Editor: Clifford Gold

Copyright (C) 2017 Charei Munene Waweru et al. This is an open access article distributed under the Creative Commons Attribution License, which permits unrestricted use, distribution, and reproduction in any medium, provided the original work is properly cited.

Sodom apple (Solanum incanum L.) fruit extracts were tested for their potential to manage root knot disease caused by Meloidogyne spp. in chilli (Capsicum annuum L.). The effect of sodom apple fruit extracts at different concentrations on the plant height, leaf number, stem diameter, number of galls, and nitrogen and phosphorous levels in chilli infected with root knot nematodes was evaluated. The efficacy of sodom apple fruit extracts against the root knot nematodes was tested under glasshouse and field conditions. All treatment effects were determined by one-way ANOVA using SAS program (Version 9.3). Evaluation after treatment of plants with sodom apple fruit extracts showed that there was a significant difference $(P=0.05)$ in plant heights, number of galls, leaf number, and nitrogen levels in chilli. In the field experiment, the highest mean heights were recorded in the $100 \%$ treatment (T1) during the first and third reading. Chilli plants that were treated with the sodom apple fruit extract had a significantly high number of leaves. In the greenhouse experiment, the positive control (T6) had the highest mean heights followed by the $50 \%$ treatment (T2). Our research results showed that sodom apple fruit extracts have nematicidal compounds with a potential to be used in the management of chilli root knot nematodes.

\section{Introduction}

Chilli (Capsicum annuum L.) is attacked by root knot nematodes which reduce the yields significantly. Losses due to nematode infestation in chilli are about $23 \%$ [1]. The use of chemicals in control of nematodes has been faced with challenges due to its effect on the environment. The withdrawal of methyl bromide as a soil fumigant has triggered research into alternative methods of nematode control [2]. In the recent past different plant extracts have been used in the control of various diseases and pests in crops [3]. Various leaf extracts of noxious weeds such as Solanum xanthocarpum and Argemone mexicana have been used as bare-root dip treatment for the management of plant-parasitic nematodes $[4,5]$. Sodom apple (Solanum incanum) plants are readily available in tropical and subtropical areas growing naturally as shrubs in open fields, along the roads or as weeds. The evaluation of the potential nematicidal activity of sodom apple fruits will be helpful in formulation of environmentally friendly nematicides. The objective of the present study was to test the efficacy of sodom apple fruit extracts on their ability to reduce root knot nematode infestation in chilli ( $C$. annuum).

\section{Materials and Methods}

Nematode population was multiplied in chilli (Oiseau variety from Technisem, France) over a period of 4 months. This nematode population was used as the stock in the experiment. C. annuum seeds were germinated in a seed bed under nonheated greenhouse conditions for a period of one month. Soil that was used in the experiment was steam sterilized at $100^{\circ} \mathrm{C}$ in a metal drum [6]. The soil was allowed to cool and was put in plastic pots. The ripe and unripe fruits of sodom apple were washed with distilled water and blended with distilled water. Three hundred grams of fruits were dissolved in one liter of water. The extracted juice was passed through 
a double layered cheese cloth. This formed the standard 100\% plant extract. Four dilutions were made [7].

The experiment was laid in completely randomized design with three replicates in the greenhouse. The field experiment was laid in completely randomized block design with three replicates. Each replicate had six pots; four seedlings were planted per pot. The soil in each pot was treated with nematodes eggs suspended in $50 \mathrm{~mL}$ of water. There were approximately 5000 nematode eggs per $\mathrm{mL}$ [8]. Six treatments were imposed on the soil bearing nematodes in each replicate. The treatments were applied once. The four levels of sodom apple fruit extracts derived earlier were used (100\% labeled T1, 50\% labeled T2, 25\% labeled T3, and $12.5 \%$ labeled T4). The positive control was a nematicide by the market name Nimbecidine labeled T6. The active ingredient is azadirachtin (0.03\%) and neem oil (90.57\%) applied at the rate of six-eight $\mathrm{mL} / \mathrm{m}^{2}$. The negative control used was tap water labeled T5. Watering was done regularly. Data collection for mean heights, leaf numbers, and stem diameter was done monthly after planting of seedlings; data was recorded thrice. The data for root galls was collected after two months from planting to allow gall formation. Chilli leaves were harvested after two months. The leaves were oven dried at $60^{\circ} \mathrm{C}$ for 12 hours. They were then crushed using an electric grinder and suspended in water. Total nutrient analysis was done using Kjeldahl oxidation method [9].

The determination of nitrogen level was done by putting $5 \mathrm{mLs}$ of an aliquot to a Kjeltec auto distillation apparatus (Model 2200). The ammonia in the distillate was collected in a receiver with excess boric acid and an indicator. Blank determination was done by digesting reagents in place of the sample and distilling and titrating with $\mathrm{N} / 70 \mathrm{HCl}$ as for the samples. The percentage of nitrogen $(\mathrm{N})$ in the plant tissue was determined by the following formula [9]:

$$
\begin{aligned}
& \% \mathrm{~N} \text { in plant sample } \\
& =\frac{\text { Corrected } \mathrm{mL} \text { of } \mathrm{N} / 70 \mathrm{HCl} * 0.2}{\text { Weight of sample in grams }} .
\end{aligned}
$$

The determination of phosphorous level was done by putting $5 \mathrm{mLs}$ of supernatant wet-ashed digested solution to a $50 \mathrm{~mL}$ volumetric using a pipette. Twenty $\mathrm{mL}$ of distilled water was added to each flask. Ten $\mathrm{mL}$ of ascorbic acid was added and then made to $50 \mathrm{~mL}$ with distilled water.

The solution was allowed to stand for 1 hour to permit full colour development. The standard and sample absorbance (blue colour) was measured at $880 \mathrm{~nm}$ wavelength using a spectrophotometer (Model Pharmacia Biotech).

The total phosphorous percentage was computed as

$$
\% \mathrm{P} \text { in plant sample }=\frac{C * 0.05}{W},
$$

where $C$ is the corrected concentration, * means multiplication, $\mathrm{P}$ is phosphorous, and $W$ is the weight of the sample in grams [9].

By the end of the experiment most chilli plants had reached flowering stage. Means and standard errors of the means are given for all data. The data was subjected to oneway ANOVA using SAS program (Version 9.3).
TABLE 1: Means of chilli heights.

\begin{tabular}{lccc}
\hline Treatments & Height 1 & Height 2 & Height 3 \\
\hline T1 & $15^{\mathrm{a}}$ & $20.3^{\mathrm{ab}}$ & $25.7^{\mathrm{a}}$ \\
T2 & $15^{\mathrm{a}}$ & $21.7^{\mathrm{a}}$ & $23.3^{\mathrm{ab}}$ \\
T5 & $13^{\mathrm{ab}}$ & $20.3^{\mathrm{ab}}$ & $22.7^{\mathrm{ab}}$ \\
T4 & $13^{\mathrm{ab}}$ & $16.7^{\mathrm{b}}$ & $20.7^{\mathrm{b}}$ \\
T6 & $11.7^{\mathrm{ab}}$ & $18.3^{\mathrm{ab}}$ & $23^{\mathrm{ab}}$ \\
T3 & $10.7^{\mathrm{b}}$ & $16.7^{\mathrm{b}}$ & $18.7^{\mathrm{b}}$ \\
\hline
\end{tabular}

${ }^{\mathrm{ab}}$ In the column, means followed by the same letter are not significantly different from each other at $P=0.05$ according to Least Significant Difference (LSD) test.

TABLE 2: Means of chilli gall numbers.

\begin{tabular}{lcc}
\hline Treatments & Gall 1 & Gall 2 \\
\hline T1 & $9.3^{\mathrm{a}}$ & $10.7^{\mathrm{b}}$ \\
T2 & $5.3^{\mathrm{ab}}$ & $11.3^{\mathrm{b}}$ \\
T6 & $4^{\mathrm{b}}$ & $23.3^{\mathrm{a}}$ \\
T4 & $3.7^{\mathrm{b}}$ & $15.3^{\mathrm{ab}}$ \\
T3 & $3^{\mathrm{b}}$ & $9^{\mathrm{b}}$ \\
T5 & $3^{\mathrm{b}}$ & $11.3^{\mathrm{b}}$ \\
\hline
\end{tabular}

${ }^{\mathrm{ab}}$ In the column, means followed by the same letter are not significantly different from each other at $P=0.05$ according to Least Significant Difference (LSD) test.

\section{Results and Discussion}

3.1. Sodom Apple Fruit Extracts Field Experiment Results. During the first reading, the $50 \%$ treatment (T2) and the $100 \%$ treatment (T1) had the highest mean heights. The lowest mean height was in the $25 \%$ treatment (T3). During the second reading, the highest mean height was in the $50 \%$ treatment (T2), while the lowest mean height was in the $12.5 \%$ treatment (T4). There was a general increase in height in comparison with the previous reading. During the third reading, the $100 \%$ treatment (T1) had the highest mean height, while the $25 \%$ treatment (T3) had the lowest mean height. There was significant difference in the mean heights when different treatments of sodom apple fruits extracts were used as shown in Table 1.

During the first reading, the highest number of galls was recorded in the $100 \%$ treatment (T1) followed by the $50 \%$ treatment (T2). The lowest number of galls was recorded in the $25 \%$ treatment (T3) and the negative control (T5). During the second reading, the highest number of galls was recorded in the positive control (T6) followed by the $12.5 \%$ treatment (T4). The lowest number of galls recorded was in the $25 \%$ treatment (T3) followed by the $100 \%$ treatment (T1). There was significant difference in the mean number of galls recorded as shown in Table 2.

There was significant difference on the mean number of leaves when different treatments of sodom apple fruit extracts were used during the first reading only. The highest number of leaves was found in the $50 \%$ (T2) treatment, while the lowest means were in the negative and positive control. There was a general increase in the mean number of leaves across the three readings as shown in Table 3. 
TABLE 3: Means of chilli leaf numbers.

\begin{tabular}{lccc}
\hline Treatments & Leaf 1 & Leaf 2 & Leaf 3 \\
\hline T2 & $24^{\mathrm{a}}$ & $29.7^{\mathrm{a}}$ & $27.7^{\mathrm{a}}$ \\
T4 & $21^{\mathrm{a}}$ & $29.3^{\mathrm{a}}$ & $38.3^{\mathrm{a}}$ \\
T1 & $20.7^{\mathrm{a}}$ & $24.3^{\mathrm{a}}$ & $34^{\mathrm{a}}$ \\
T5 & $16.3^{\mathrm{ab}}$ & $25^{\mathrm{a}}$ & $52^{\mathrm{a}}$ \\
T6 & $16.3^{\mathrm{ab}}$ & $33.7^{\mathrm{a}}$ & $49.7^{\mathrm{a}}$ \\
T3 & $15.7^{\mathrm{b}}$ & $20.3^{\mathrm{a}}$ & $29.3^{\mathrm{a}}$ \\
\hline
\end{tabular}

${ }^{\mathrm{ab}}$ In the column, means followed by the same letter are not significantly different from each other at $P=0.05$ according to Least significant Difference (LSD) test.

TABLE 4: Means of nitrogen and phosphorous levels.

\begin{tabular}{lcccc}
\hline Treatments & $\mathrm{N} 1$ & $\mathrm{~N} 2$ & $\mathrm{P} 1$ & $\mathrm{P} 2$ \\
\hline T2 & $1.1^{\mathrm{b}}$ & $1.2^{\mathrm{a}}$ & $299^{\mathrm{a}}$ & $2108^{\mathrm{a}}$ \\
T4 & $1.1^{\mathrm{b}}$ & $1.2^{\mathrm{a}}$ & $287^{\mathrm{a}}$ & $1807^{\mathrm{a}}$ \\
T1 & $2^{\mathrm{ab}}$ & $2.9^{\mathrm{a}}$ & $3936^{\mathrm{a}}$ & $1366^{\mathrm{a}}$ \\
T5 & $2^{\mathrm{ab}}$ & $1.6^{\mathrm{a}}$ & $2128^{\mathrm{a}}$ & $4022^{\mathrm{a}}$ \\
T6 & $1.8^{\mathrm{b}}$ & $1.6^{\mathrm{a}}$ & $543^{\mathrm{a}}$ & $1586^{\mathrm{a}}$ \\
T3 & $3.8^{\mathrm{a}}$ & $2.5^{\mathrm{a}}$ & $750^{\mathrm{a}}$ & $2705^{\mathrm{a}}$ \\
\hline
\end{tabular}

${ }^{\mathrm{ab}}$ In the column, means followed by the same letter are not significantly different from each other at $P=0.05$ according to Least significant Difference (LSD) test.

TABLE 5: Means of chilli heights.

\begin{tabular}{lccc}
\hline Treatments & Height 1 & Height 2 & Height 3 \\
\hline T1 & $9.3^{\mathrm{b}}$ & $19^{\mathrm{a}}$ & $25^{\mathrm{a}}$ \\
T2 & $11^{\mathrm{ab}}$ & $17^{\mathrm{a}}$ & $20^{\mathrm{a}}$ \\
T5 & $10.3^{\mathrm{ab}}$ & $17^{\mathrm{a}}$ & $25.3^{\mathrm{a}}$ \\
T4 & $9.7^{\mathrm{ab}}$ & $12.7^{\mathrm{a}}$ & $11.3^{\mathrm{a}}$ \\
T6 & $12.7^{\mathrm{a}}$ & $21.7^{\mathrm{a}}$ & $24^{\mathrm{a}}$ \\
T3 & $8.3^{\mathrm{b}}$ & $14.7^{\mathrm{a}}$ & $25.3^{\mathrm{a}}$ \\
\hline
\end{tabular}

${ }^{\mathrm{ab}}$ In the column, means followed by the same letter are not significantly different from each other at $P=0.05$ according to Least Significant Difference (LSD) test.

There was significant difference in the nitrogen levels for the treatments during the first reading. The highest nitrogen levels were recorded in the $25 \%$ treatment followed by the $100 \%$ and negative control treatments. The lowest nitrogen level was recorded in the $12.5 \%$ treatment and 50\% treatment as shown in Table 4.

There was no significant difference in the means of stem diameters when different treatments of sodom apple fruit extracts were used in the field experiment.

3.2. Sodom Apple Fruit Extracts Greenhouse Experiment Results. During the first reading of the greenhouse experiment the highest heights were recorded in the positive control (T6) followed by the $50 \%$ treatment (T2) and negative control treatment (T5), respectively. The lowest height reading was recorded in the $25 \%$ treatment (T3). During the second and third reading there was no significant difference in the means of heights as shown in Table 5.
TABLE 6: Means of nitrogen and phosphorous levels.

\begin{tabular}{lcccc}
\hline Treatments & $\mathrm{N} 1$ & $\mathrm{~N} 2$ & $\mathrm{P} 1$ & $\mathrm{P} 2$ \\
\hline T2 & $0.9^{\mathrm{bc}}$ & $1.2^{\mathrm{a}}$ & $863.3^{\mathrm{a}}$ & $1276.7^{\mathrm{a}}$ \\
T4 & $1.3^{\mathrm{a}}$ & $1.1^{\mathrm{a}}$ & $256.1^{\mathrm{a}}$ & $848.3^{\mathrm{a}}$ \\
T1 & $1.2^{\mathrm{abc}}$ & $1.1^{\mathrm{a}}$ & $782.2^{\mathrm{a}}$ & $1335.6^{\mathrm{a}}$ \\
T5 & $0.9^{\mathrm{abc}}$ & $1.1^{\mathrm{a}}$ & $801.7^{\mathrm{a}}$ & $732.8^{\mathrm{a}}$ \\
T6 & $0.8^{\mathrm{c}}$ & $1^{\mathrm{a}}$ & $1240^{\mathrm{a}}$ & $256.7^{\mathrm{a}}$ \\
T3 & $1.2^{\mathrm{ab}}$ & $1.2^{\mathrm{a}}$ & $803.9^{\mathrm{a}}$ & $815.6^{\mathrm{a}}$ \\
\hline
\end{tabular}

${ }^{\mathrm{ab}}$ In the column, means followed by the same letter are not significantly different from each other at $P=0.05$ according to Least significant Difference (LSD) test.

There was no significant difference in the mean number of leaves, stem diameters, and number of galls when different treatments of sodom apple fruit extracts were used in the greenhouse experiment.

There was significant difference in the nitrogen levels during the first reading. During the first reading, the highest nitrogen levels were recorded in the $12.5 \%$ treatment followed by the $25 \%$ treatment. The lowest nitrogen level was recorded in the positive control treatment followed by the $50 \%$ treatment as shown in Table 6.

\section{Discussion}

In this experiment, the effect of different treatments of sodom apple fruit extracts was found to be significant. The active compound in sodom apple is solanine. In the field experiment the $100 \%$ treatment and 50\% treatment had the highest mean height. This is probably due to the fact that the sodom apple fruit extracts eradicated a large number of nematodes leading to proficient growth [5]. The fact that the $25 \%$ treatment had a general low mean height could be attributed to the fact that the treatment was more dilute than the $100 \%$ and $50 \%$ treatment resulting in low nematicidal activity. The means of leaf numbers were only significant during the first reading. High means of leaf numbers in the $50 \%$ treatment could be attributed to better water and nutrient uptake due to reduced nematode population. Nematodes have been known to affect water and nutrient uptake due to vascular dysfunction [10]. The $25 \%$ treatment had the lowest number of leaves; this would be attributed to poor water and nutrient uptake due to more deformed roots caused by a higher nematode population. A good vascular system would lead to better nitrogen uptake. Increased nitrogen levels were found to increase the total number of leaves [11]. During the first reading, the presence of a high number of galls in the positive control treatment would be due to low activity of the nematicide at a single application. The activity of the nematicide was more pronounced in the second reading where the galling in the positive control treatment had the second lowest mean. The low number of galls in the $25 \%$ treatment could be an indication it was the optimum concentration for nematicidal activity. High number of galls in the $100 \%$ (T1) treatment could be attributed to the viscous state of the treatment. It was very viscous and could have clumped together hindering proper distribution in the soil 
leading to decreased nematicidal activity. The effectiveness of plant extracts varies with the concentration [7]. In the sodom apple fruit extract field experiment, the relatively high nitrogen and phosphorous levels in the $100 \%$ treatment could be attributed to low disease severity due to higher nematicidal activity. Roots attacked by root knot nematodes exhibit characteristic root galls, and infected plants grow poorly or even die because of poor nutrient intake and vascular dysfunction. There was no significant difference in phosphorous levels in the sodom apple fruit extract field experiment. The lack of significance in phosphorous uptake could be as a result of variability of phosphorous which is dependent on environmental factors and plant root characteristics. High mean heights in the positive control (T6) of the greenhouse experiment could be attributed to better water and nutrient uptake due to increased nematicidal activity [8]. The 50\% (T2) treatment also had high mean heights probably due to low galling of chilli plants. High nitrogen levels in the $12.5 \%$ and $100 \%$ treatment during the first reading in the sodom apple fruit greenhouse experiment could be as a result of low disease severity due to increased nematicidal effect [10]. Lack of significant difference in nitrogen levels during the second reading and phosphorous levels for both readings is a possible indication of low disease severity. Previous reports indicate phosphorous fertilizers are known to reduce disease severity. Nitrogen levels have been found to have significant effect on the total plant weight including number of leaves. Increased nitrogen levels increased the total number of leaves [11]. Earlier studies show that root knot nematodes have complex trophic relationships with their host plant with induction of specialized feeding structures known as giant cells. Infected plants were observed to grow poorly or even die because of vascular dysfunction [10]. This finding is consistent with earlier studies that found larval penetration of second stage juveniles of $M$. incognita was inhibited at various concentrations of leaf extracts and dip durations [8]. The efficacy of root-dip treatment with respect to improvement in plant weight and reduction in root knot development and nematode populations increases with increasing the concentration of leaf extracts and dip durations [12].

Reduction in the nematode population is attributed to increased concentration of various substances like ammonia, phenol formaldehyde, organic acids, hydrogen sulfide, tannins, and volatile fatty acids which suppress the nematode multiplication and gall formation $[13,14]$. Neem seed derivatives were observed to be effective in the control of Pratylenchus goodeyi in bananas [15]. In an earlier study leaf extracts of $S$. xanthocarpum cause inhibition in root knot development in case of root knot nematode as observed in egg hatchability and larval mortality tests [16]. There was significant reduction in the root knot development caused by $M$. incognita, multiplication of nematode populations of $R$. reniformis and T. brassicae on test plants [8]. Wild Solanum spp. root stocks have been evaluated for development of tomatoes resistant to root knot nematodes. The highest shoot length, shoot fresh, and dry weight were found in Solanum sisymbriifolium. Moderate resistance was found in Solanum incanum [17].
The findings on the effectiveness of sodom apple fruit extracts in the control of root knot nematodes in this research provides a potential source of information that can be used in control of root knot nematodes.

\section{Conclusions}

The fruit extracts of sodom apple had a significant effect on various growth parameters in chilli. Sodom apple fruit extracts were found to have significant nematicidal activity and can therefore be used as a more effective and environmentally friendly control of root knot nematodes. They can be recommended to farmers and other stakeholders as part of the integrated management system in chilli. The fact that there was significant effect on nitrogen uptake in both the field and greenhouse experiments when chilli were infected with root knot nematodes is a clear proof that root knot nematodes affect nutrient intake. This information will be crucial to agronomists when formulating applications of nitrogen and phosphorous based fertilizers. More plants known to have medicinal properties should also be evaluated for nematicidal activity.

\section{Conflicts of Interest}

There are no conflicts of interest with the Egerton University Department of Biological Sciences or any other party regarding the publication of this manuscript.

\section{Acknowledgments}

The authors take this opportunity to pass their sincere gratitude to their apt supervisors Dr. Japhet Mburugu Muthamia and Professor Daniel Otieno Otaye of the Department of Biological Sciences, Egerton University, for their tireless input in this research. They also appreciate the effort of Mr. Francis Ngumbu, Chief Technologist, Department of Biological Sciences, Egerton University, who guided them on various laboratory methods. They also appreciate Ms. Naomi Njoki who helped them in data collection.

\section{References}

[1] S. A. Anwar and M. V. McKenry, "Incidence and population density of plant-parasitic nematodes infecting vegetable crops and associated yield losses in Punjab, Pakistan," Pakistan Journal of Zoology, vol. 44, no. 2, pp. 327-333, 2012.

[2] R. W. D. Taylor, "Methyl bromide-is there any future for this noteworthy fumigant?" Journal of Stored Products Research, vol. 30, no. 4, pp. 253-260, 1994.

[3] Y. Oka, S. Nacar, E. Putievsky, U. Ravid, Z. Yaniv, and Y. Spiegel, "Nematicidal activity of essential oils and their components against the root-knot nematode," Phytopathology, vol. 90, no. 7, pp. 710-715, 2000.

[4] M. M. Guerrero-Diaz, C. M. Lacasa-Martinez, A. HernandezPiñera, V. Martinez-Alarcon, and A. Lacasa Plasencia, "Evaluation of repeated biodisinfestation using Brassica carinata pellets to control Meloidogyne incognita in protected pepper crops," Spanish Journal of Agricultural Research, vol. 11, no. 2, pp. 485493, 2013. 
[5] J. A. Bawa, I. Mohammed, and S. Liadi, "Nematicidal effects of some plant extracts on Root knot nematodes (Meloidogyne incognita) of Tomato (Lycopersicon esculentum)," World Journal of Life Sciences and Medical research, vol. 3, no. 3, article 81, 2014.

[6] K.-H. Wang and R. McSorley, "Exposure time to lethal temperatures for Meloidogyne incognita suppression and its implication for soil solarization," Journal of Nematology, vol. 40, no. 1, pp. 7-12, 2008.

[7] M. Pavaraj, G. Bakavathiappan, and S. Baskaran, "Evaluation of some plant extracts for their nematicidal properties against root-knot nematode, Meloidogyne incognita," Journal of Biopesticides, 5, pp. 106-110.

[8] J. M. Muthamia, Responses of cowpea (Vigna unguiculata (L.)Walp) cultivars to the root knot nematode (Meloidogyne incognita) and the nematodes responses to different plant extracts [Ms.c thesis], Egerton University, Njoro, Kenya, 2004.

[9] J. R. Okalebo and R. L. Woomer, "Laboratory methods of soil and plant analysis: a working manual," Soil Science Society of East African Technical Publication 1, Marvel E.P.Z (Kenya) LTD, Nairobi, Kenya, 1993.

[10] R. S. Hussey and G. J. W. Janssen, Plant Resistance to Parasitic Nematodes, CABI Publication, Oxfordshire, UK, 2002.

[11] L. W. Mauyo, V. E. Anjichi, G. W. Wambugu, and M. E. Omunyini, "Effect of nitrogen fertilizer levels on fresh leaf yield of spider plant (Cleome gynandra) in Western Kenya," Scientific Research and Essay, vol. 3, no. 6, pp. 240-244, 2008.

[12] S. A. Tiyagi and S. Ajaz, "Possible utilization of weeds for the management of plant parasitic nematodes infesting some vegetable crops," Archives of Phytopathology and Plant Protection, vol. 36, no. 2, pp. 95-102, 2003.

[13] Y. Oka, B.-H. Ben-Daniel, and Y. Cohen, "Control of Meloidogyne javanica by formulations of Inula viscosa leaf extracts," Journal of Nematology, vol. 38, no. 1, pp. 46-51, 2006.

[14] K.-H. Wang, R. McSorley, and R. N. Gallaher, "Effect of Crotalaria juncea amendment on squash infected with Meloidogyne incognita," Journal of Nematology, vol. 36, no. 3, pp. 290-296, 2004.

[15] T. Musabyimana and R. C. Saxena, "Efficacy of neem seed derivatives against nematodes affecting banana," Phytoparasitica, vol. 27, no. 1, pp. 43-49, 1999.

[16] C. Azhagumurugan, M. K. Rajan, and M. Pavaraj, "Effect of root knot nematode, Meloidogyne incognita on the growth characteristics of Horse Gram, Macrotylona uniflorum treated with fruit extracts of Aegle marmelos," World Journal of Zoology, vol. 9, no. 3, pp. 162-165, 2014.

[17] R. Dhivya, A. Sadasakthi, and M. Sivakumar, "Response of wild solanum rootstocks to root-knot nematode (Meloidogyne incognita)," International Journal of Plant Sciences, vol. 9, no. 1, pp. 117-122, 2014. 


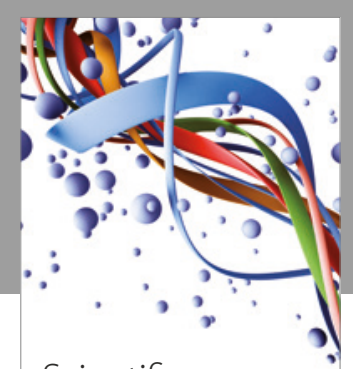

Scientifica
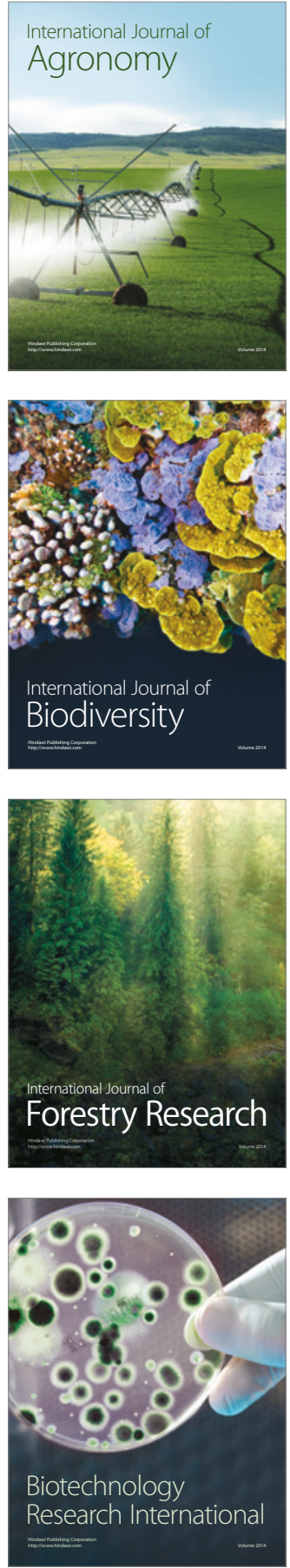
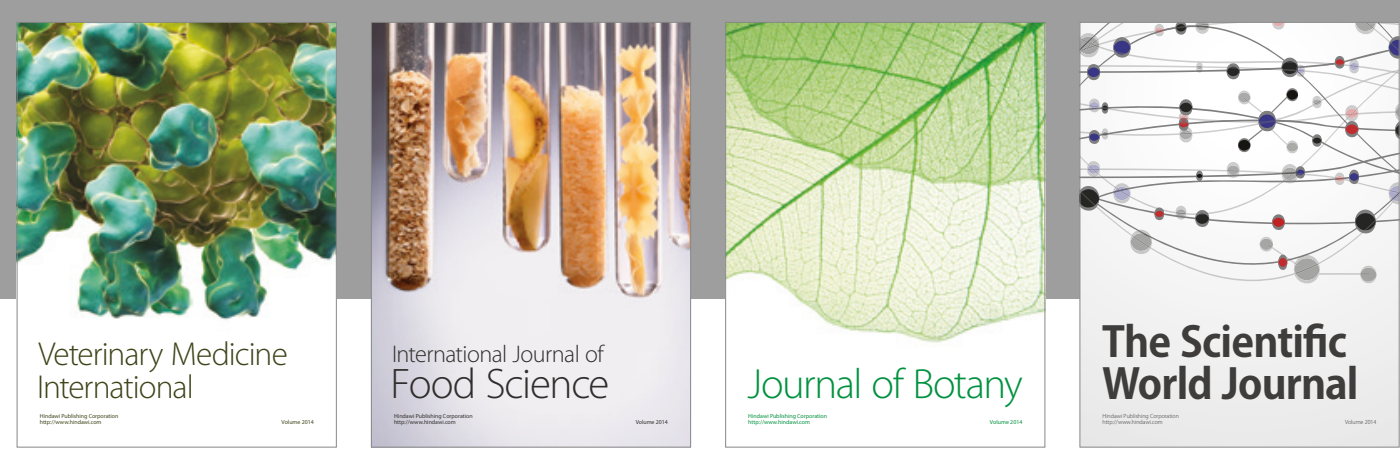

The Scientific

\section{World Journal}

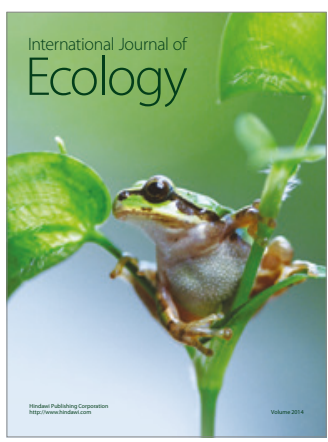

\section{Hindawi}

Submit your manuscripts at

https://www.hindawi.com
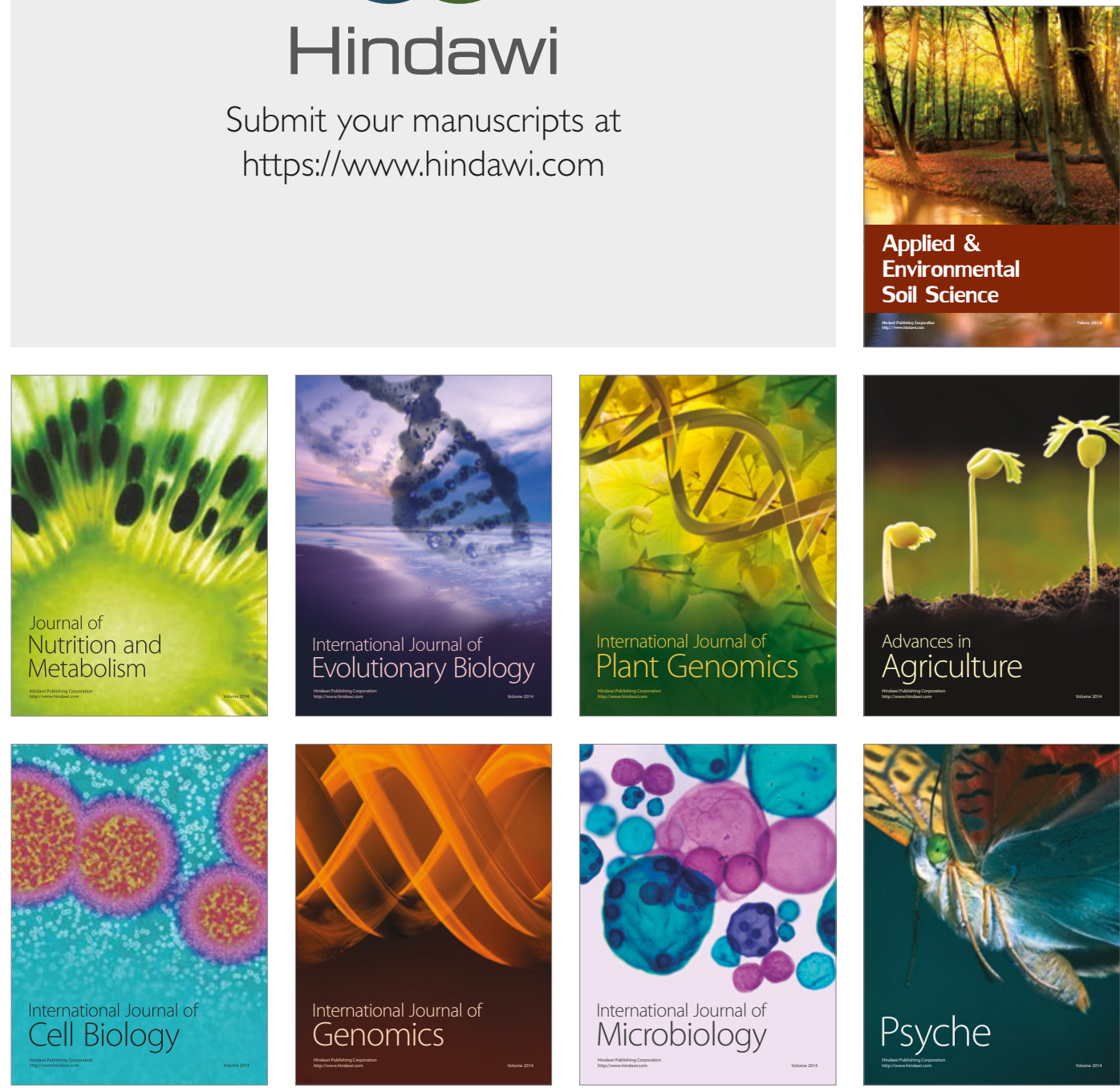

hternational Journal of Microbiology
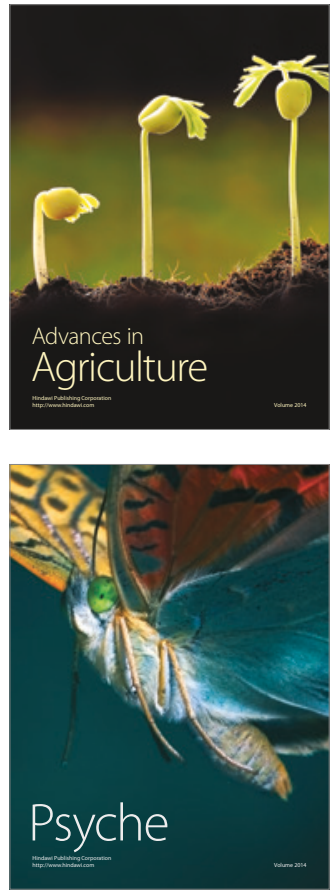